p-ISSN: $2338-4794$

e-ISSN: 2579-7476

Vol.8. No. 1 Januari-April 2020

\title{
PENGARUH KARAKTERISTIK INDIVIDU DAN FAKTOR LINGKUNGAN TERHADAP KEPUTUSAN PEMBELIAN (Studi Pada Pembelian Produk Asuransi Jiwa Unit Link Di Jakarta)
}

\author{
Devi Krisnawati *) \\ *) Dosen Program Studi Manajemen FE-UNKRIS \\ Alamat: Kampus UNKRIS, Jatiwaringin Jakarta Timur \\ Email : devikrisnawati@gmail.com
}

\begin{abstract}
This research use descriptive research with quantitative approach. There are three variables that are used in this research: Individual Differences, Environmental Factors and Buying Decision. The collection of data obtained through online questionnaires, which were distributed randomly in Jakarta. The sample in this research was 100 respondents. The sampling technique of this research is random sampling. The data analysis uses descriptive analysis and multiple linear regressions. The results in this research showed that Individual Differences and Environmental Factors simultaneously affecting Buying Decision significantly. The other results showed that Individual Difference and Environmental Factors partially affecting Buying Decision significantly. Based on the result of this research, it's better for Insurance Company to considerate people personal individual differences and also environmental factors to strengthen the sales of unit link product.
\end{abstract}

\section{Keywords: Individual differences, environmental factors and buying decision}

\section{PENDAHULUAN}

Produk asuransi jiwa saat ini semakin bervariasi, salah satu produk asuransi jiwa yang memiliki demand cukup tinggi saat ini adalah asuransi jiwa yang juga berbasis produk investasi yaitu unit link. (Kontan, 2019) Asuransi Jiwa Unit Link adalah kontrak asuransi yang memberikan manfaat perlindungan dengan premi rendah sekaligus investasi. Jenis asuransi ini memberikan manfaat perlindungan asuransi kematian dan investasi sekaligus. (OJK, 2019) Dalam suatu perencanaan keuangan, investasi dan proteksi merupakan dua hal wajib untuk dimiliki. Investasi diperlukan untuk mencapai tujuan keuangan, misalnya dana pendidikan dan dana pensiun, sementara proteksi untuk dapat menjamin tujuan keuangan tetap bisa dicapai apabila terjadi resiko yang tidak dapat dihindari. Menurut data Asosiasi Asuransi Jiwa Indonesia (AAJI) produk asuransi jiwa berbasis investasi atau unitlink memiliki kontribusi yang signifikan terhadap total premi keseluruhan di Kuartal III 2019 sebesar Rp 171,83 triliun, dibandingkan dengan produk asuransi tradisional. Total premi Asuransi Jiwa dari unit link menyumbang porsi $63 \%$ terhadap total premi sedangkan premi tradisional menyumbang porsi sebesar $37 \%$ terhadap total premi. (Kontan, 2019). Sedangkan untuk premi baru, produk unit link berkontribusi sebesar Rp. 89,98 triliun atau $57,1 \%$ terhadap total premi baru dibandingkan dengan produk tradisional yang berkontribusi sebesar 42,9\% pada periode kuartal III 2019 (AAJI, 2019)

Walaupun demikian, penetrasi industri asuransi di Indonesia masih terbilang rendah. Sampai dengan tahun 2019, penetrasi industri asuransi di Indonesia masih sekitar tiga persen, dimana rata-rata pengeluaran masyarakat Indonesia untuk membayar asuransi 
hanya 1,6 juta per tahun (OJK pada Kontan, 2019) artinya kesadaran masyarakat Indonesia tentang pentingnya asuransi masih rendah. Hal tersebut bisa menjadi tantangan dan juga peluang untuk para pemain industri asuransi khususnya produk unit link. Menyertai pertumbuhannya, asuransi jiwa unit-link juga banyak menimbulkan kontroversi dan perdebatan, karena produk unit-link merupakan produk asuransi jiwa yang cukup kompleks dan membutuhkan pemahaman yang cukup mendalam terkait proteksi maupun investasi, sehingga banyak terjadi kasus mis-selling akibat informasi yang disampaikan oleh tenaga pemasar atau pemahaman nasabah yang menerima informasi kurang menyeluruh. (Detikfinance, 2019) Selain itu, sebagai produk proteksi yang juga memberikan manfaat investasi mengakibatkan biaya yang ditimbulkan pada produk unit-link cenderung lebih besar dibandingkan dengan produk proteksi atau produk investasi, hal ini menyebabkan banyak perencana keuangan yang tidak merekomendasikan unit-link sebagai produk yang menguntungkan (Diskartes, 2017). Kasus-kasus tersebut tentu saja banyak menimbulkan ulasan-ulasan negatif yang dapat mempengaruhi minat konsumen terhadap asuransi unit-link sehingga beresiko pada penjualan unit-link. Berdasarkan fenomena tersebut, peneliti tertarik untuk meneliti faktor-faktor yang dapat mempengaruhi konsumen dalam proses keputusan pembelian produk asuransi jiwa unit-link. Dalam penelitian ini faktor-faktor tersebut dibatasi kedalam dua lingkup: faktor internal, yaitu dari dalam diri konsumen tersebut atau yang disebut dengan karakter individu dan faktor eksternal, yaitu yang berasal dari lingkungan konsumen.

Penelitian ini bertujuan untuk mencari pengaruh dari karakter individu dan faktor lingkungan terhadap keputusan pembelian produk asuransi jiwa unitlink.

\section{LANDASAN TEORI}

\section{Keputusan Pembelian}

Keputusan Pembelian Menurut Kotler, adalah tindakan dari konsumen untuk mau membeli atau tidak terhadap produk. Sebelum konsumen memutuskan untuk membeli, biasanya konsumen melalui beberapa tahap terlebih dahulu yaitu, (1) Pengenalan masalah; Sebelum terjadi pembelian, proses pengambilan keputusan dimulai ketika konsumen mengenali dan menyadari adanya masalah atau kebutuhan yang dapat menjadi motif dasar pembelian. Kebutuhan tersebut dapat dicetuskan oleh rangsangan internal atau eksternal. (2) Pencarian informasi; Konsumen yang sudah menyadari dan mengenali kebutuhannya akan terdorong untuk mencari informasi informasi yang lebih banyak terhadap barang atau jasa yang dapat memenuhi kebutuhannya tersebut. Dalam tahap ini, pencarian informasi yang dilakukan oleh konsumen dapat dibagi ke dalam dua level, yaitu situasi pencarian informasi yang lebih ringan dinamakan dengan penguatan informasi. Pada level ini orang akan mencari serangkaian informasi tentang sebuah produk. Pada level kedua, konsumen mungkin akan mungkin masuk kedalam tahap pencarian informasi secara aktif. Mereka akan mencari informasi melalui bahan bacaan, pengalaman orang lain, dan mengunjungi toko untuk mempelajari produk tertentu.

Menurut Kotler sumber utama yang menjadi tempat konsumen untuk mendapatkan informasi dapat digolongkan kedalam empat kelompok, yaitu: a). Sumber pribadi: keluarga, teman, tetangga dan kenalan. b). Sumber komersial: iklan, wiraniaga, penyalur, kemasan, pajangan ditoko. c). Sumber publik: Media masa, organisasi penentu peringkat konsumen, situs pencari. d). 
Sumber pengalaman: penanganan, pengkajian, dan pemakaian produk. Secara umum, konsumen mendapatkan sebagian informasi tentang sebuah produk melalui sumber komersial-yaitu sumber yang didominasi oleh pemasar. Namun, informasi yang paling efektif berasal dari sumber pribadi. Tiap-tiap informasi komersial menjalankan perannya sebagai pemberi informasi, dan sumber pribadi menjalankan fungsi legitimasi atau evaluasi. Melalui sebuah aktivitas pengumpulan informasi, konsumen dapat mempelajari merekmerek yang bersaing beserta fitur-fitur yang dimiliki oleh setiap merek sebelum memutuskan untuk membeli merek yang mana. (3) Evaluasi alternative; adalah tahapan selanjutnya dari pencarian informasi, setelah informasi akan barang dan jasa yang dapat memenuhi kebutuhan konsumen terkumpul, konsumen akan melakukan evaluasi alternatif terhadap beberapa merek atau perusahaan penyedia barang atau jasa yang dapat memberikan produk yang sama. Pada tahap ini konsumen akan berusaha memenuhi kebutuhannya. Konsumen juga akan mencari manfaat tertentu dari solusi produk dan konsumen akan memandang masing-masing produk sebagai sekumpulan atribut dengan kemampuan yang berbeda-beda dalam memberikan manfaat yang digunakan dan untuk memuaskan kebutuhannya. (4) Keputusan pembelian; Pada tahapan keputusan pembelian, konsumen dipengaruhi oleh dua faktor utama yang terdapat diantara niat pembelian dan keputusan pembelian yaitu: a). Sikap orang lain, yaitu sejauh mana sikap orang lain mengurangi alternatif yang disukai seseorang akan bergantung pada dua hal. Pertama, intensitas sikap negatif orang lain terhadap alternatif yang disukai calon konsumen. Kedua, motivasi konsumen untuk menuruti keinginan orang lain. Semakin gencar sikap negatif orang lain dan semakin dekat orang lain tersebut dengan konsumen, maka konsumen akan semakin mengubah niat pembeliannya. Keadaan preferensi sebaliknya juga berlaku, preferensi pembeli terhadap merek tertentu akan meningkat jika orang yang ia sukai juga sangat menyukai merek yang sama. b). Faktor yang kedua adalah faktor situasi yang tidak terantisipasi yang dapat mengurangi niat pembelian konsumen atau sebaliknya. Contohnya, konsumen mungkin akan kehilangan niat pembeliannya ketika ia kehilangan pekerjaannya atau adanya kebutuhan yang lebih mendesak pada saat yang tidak terduga sebelumnya atau adanya promo atau diskon yang mendesak sehingga konsumen merasa harus melakukan keputusan pembelian segera. Keputusan konsumen untuk memodifikasi, menunda atau menghindari keputusan pembelian sangat dipengaruhi oleh risiko yang dipikirkan. Seperti jumlah uang yang akan dikeluarkan, ketidakpastian atribut dan besarnya kepercayaan diri konsumen. Dan (5) Perilaku pasca pembelian; Setelah membeli produk, konsumen akan mengalami level kepuasan atau ketidakpuasan tertentu. Kepuasan pembeli merupakan fungsi dari sberapa dekat harapan pembeli atas produk dengan kinerja yang dipikirkan pembeli atas produk tersebut. Jika kinerja produk lebih rendah daripada harapan, pembeli akan kecewa. Sebaliknya, jika kinerja produk lebih tinggi dibandingkan harapan konsumen maka pembeli akan merasa puas. Perasaan-perasaan itulah yang akan memutuskan apakah konsumen akan membeli kembali merek yang telah dibelinya dan memutuskan untuk menjadi pelanggan merek tersebut atau merferensikan merek tersebut kepada orang lain. Kepuasan dan ketidakpuasan terhadap produk akan mempengaruhi perilaku konsumen selanjutnya. Jika konsumen merasa puas ia akan menunjukkan kemungkinan yang lebih tinggi untuk membeli kembali produk 
tersebut. Sebaliknya jka konsumen merasa tidak puas, maka ia mungkin tidak akan membeli kembali merek tersebut. (Kotler, 2006).

Menurut Kotler dan Keller ada beberapa faktor yang mempengaruhi perilaku konsumen adalah faktor lingkungan yang terdiri dari budaya, kelas sosial, keluarga dan situasi. Dan perbedaan individu, yang terdiri dari sumber daya konsumen, motivasi, pengetahuan, sikap, kepribadian, gaya hidup, dan demografi. Perbedaan individu merupakan faktor internal (interpersonal) yang menggerakkan serta mempengaruhi perilaku konsumen dalam mengambil keputusannya. (Kotler, 2006)

\section{Faktor Lingkungan}

Budaya, seperti digunakan dalam di dalam studi perilaku konsumen, mengacu pada nilai, gagasan, artefak dan simbolsimbol lain yang bermakna yang membantu individu untuk berkomunikasi, melakukan penafsiran dan evaluasi sebagai anggota masyarakat (Engel, et al, 1994). Kelas sosial adalah pembagian di dalam masyarakat terdiri dari individuindividu yang berbagi nilai, minat dan perilaku yang sama (Engel, et al, 1994). Pengaruh pribadi adalah subjek yang penting di dalam penelitian konsumen mengenai perilaku lisan dan bentukbentuk pengaruh lain dalam pengambilan keputusan konsumen (Engel, et al, 1994). Keputusan konsumen dipengaruhi oleh keluarga, maksudnya adalah banyak produk yang dibeli oleh konsumen tergantung keluarga inti dan anggota keluarga lain. Keluarga adalah kelompok yang terdiri dari dua atau lebih orang yang berhubungan melalui darah, perkawinan, adopsi, dan tinggal bersama (Engel, et al, 1994).

Kelompok Referensi, Sebuah kelompok referensi (rujukan) bagi seseorang adalah kelompok-kelompok yang memberikan pengaruh langsung atau tidak langsung terhadap sikap dan perilaku seseorang (Kotler, 1999). Situasi konsumen dapat dibedakan dalam tiga jenis yaitu : situasi komunikasi, situasi pembelian, dan situasi pemakaian. Situasi komunikasi dapat didefinisikan sebagai latar dimana konsumen dihadapkan kepada komunikasi pribadi atau nonpribadi (Engel, et al, 1994).

\section{Karakteristik Individu}

Setiap manusia mempunyai karakteristik individu yang berbeda-beda antara yang satu dengan yang lainnya. Dalam Kamus Besar Bahasa Indonesia (KBBI) yang dimaksud dengan karakteristik adalah ciri atau sifat yang berkemampuan untuk memperbaiki kualitas hidup. Sedangkan individu adalah perorangan; orang seorang. Menurut Nimran karakteristik individu meliputi kepribadian, persepsi dan sikap. (Nimran, 1997), sedangkan menurut Kotler Perbedaan individu meliputi: (1). Motivasi; Motivasi adalah suatu dorongan kehendak yang menyebabkan seseorang melakukan suatu perbuatan untuk mencapai tujuan tertentu. Motivasi berasal dari kata motif yang berarti "dorongan" atau rangsangan atau "daya penggerak" yang ada dalam diri seseorang. Menurut Weiner motivasi didefenisikan sebagai kondisi internal yang membangkitkan kita untuk bertindak, mendorong kita mencapai tujuan tertentu, dan membuat kita tetap tertarik dalam kegiatan tertentu. (Elliot et al, 2000) Menurut Uno, motivasi dapat diartikan sebagai dorongan internal dan eksternal dalam diri seseorang yang diindikasikan dengan adanya; hasrat dan minat; dorongan dan kebutuhan; harapan dan cita-cita; penghargaan dan penghormatan. (Uno, 2007) Motivasi adalah sesuatu apa yang membuat seseorang bertindak menyatakan bahwa motivasi merupakan dampak dari interaksi seseorang dengan situasi yang dihadapinya (Siagian, 2004). (2). Kepribadian; Menurut Nimran 
kepribadian dapat didefinisikan sebagai keseluruhan cara bagaimana individu bereaksi dan berinteraksi dengan orang lain. (Nimran, 1997) Menurut Sofyandi dan Garniwa, kepribadian seseorang ialah seperangkat karakteristik yang relatif mantap, kecenderungan dan perangai yang sebagian besar dibentuk oleh faktor keturunan dan oleh faktor-faktor sosial, kebudayaan, dan lingkungan. (Sofyandi dan Garniwa, 2007) Menurut Gibson, kepribadian ialah pola perilaku dan proses mental yang unik, yang mencirikan seseorang. (Gibson, 2000). (3). Persepsi; Menurut Thoha persepsi pada hakikatnya adalah proses kognitif yang dialami oleh setiap orang di dalam memahami informasi tentang lingkungannya, baik lewat penglihatan, pendengaran, penghayatan, perasaan, dan penciuman. (Thoha, 2012) Menurut Robbins persepsi adalah sebuah proses dimana individu mengatur dan menginterpretasikan kesan sensori mereka guna memberikan arti bagi lingkungan mereka. (Robbins, 2008) Menurut Gibson dkk, persepsi adalah proses kognitif yang dipergunakan oleh seseorang untuk menafsirkan dan memahami dunia sekitarnya. persepsi mencakup kognisi (pengetahuan). Persepsi mencakup penafsiran obyek, tanda, dan orang dari sudut pengalaman yang bersangkutan. (Gibson et al, 2000). (4). Pengetahuan; Pengetahuan berarti segala sesuatu yg diketahui; kepandaian: atau segala sesuatu yg diketahui berkenaan dengan hal (mata pelajaran). Selain itu Pudjawidjana mengartikan pengetahuan sebagai suatu reaksi yang ada pada manusia dengan segala rangsangan yang terjadi pada alat indranya untuk melakukan pengindraan jauh pada objek tertentu. Notoatmodjo berpendapat sedikit berbeda. Ia berpendapat bahwasannya pengetahuan merupakan hasil dari daya tahunya setelah orang tersebut melakukan pengindraan jauh. Sedangkan menurut
Prijono pengetahuan didapat dari suatu nilai yang membiasakan orang tersebut mengembangkan rasa ingin tahunya. dan (5). Sikap; Sikap adalah tanggapan yang mengandung komponen-komponen kognitif, afektif, dan konaktif yang dilakukan oleh seseorang terhadap sesuatu obyek atau bentuk respons terhadap stimulasi dari lingkungan, sikap merupakan pernyataan evaluatif-positif yang artinya menyenangkan atau menyukai maupun evaluatif-negatif yang artinya tidak senang atau tidak suka terhadap suatu objek, orang, atau peristiwa. (Nimran, 1997)

\section{METODE PENELITIAN}

Penelitian ini menggunakan pendekatan kuantitatif dengan metode pengambilan data menggunakan kuesioner. Penelitian ini dilakukan di Jakarta, dengan sampel yang digunakan pada penelitian ini sebanyak 72 responden dengan menggunakan teknik random sampling menggunakan kuesioner digital. Penelitian ini menggunakan analisis regresi lenear sederhana dan berganda untuk membuktikan tiga hipotesis penelitian

\section{Hipotesis}

Berdasarkan latar belakang, penelitian terdahulu dan tinjauan teori, hipotesis dalam penelitian ini sebagai berikut: 1). Diduga faktor karakteristik individual (motivasi, kepribadian, persepsi, pengatahuan dan sikap) dan faktor lingkungan (kebudayaan, kelas sosial dan ekonomi, kelompok referensi, keluarga, situasi) mempengaruhi keputusan pembelian Asuransi Jiwa Unit link di Jakarta. 2). Diduga faktor karakteristik individual mempengaruhi keputusan pembelian Asuransi Jiwa Unit link di Jakarta. 3). Diduga faktor lingkungan juga mempengaruhi keputusan pembelian Asuransi Jiwa Unit link di Jakarta. 
HASIL PENELITIAN DAN PEMBAHASAN

\section{Hasil Penelitian}

\section{Uji Validitas}

Uji validitas adalah untuk mengetahui validasi dari data atau kesesuaian data kuesioner yang digunakan oleh peneliti dalam mengukur dan memperoleh data penelitian dari para responden. Sebuah pernyataan dalam kuesioner dinyatakan valid apabila hasil $r$ hitung > $\mathrm{r}$ tabel dan nilai signifikansi < 0.05. Pada penelitian ini, $r$ tabel yang digunakan adalah dengan $\mathrm{N}=72$ pada signifikansi $5 \%$ pada distribusi nilai $\mathrm{r}$ tabel, maka diperoleh nilai $\mathrm{r}$ tabel sebesar 0.2319 .

Berdasarkan hasil uji validitas dari penelitian ini membuktikan bahwa data yang digunakan dalam penelitian ini adalah valid, yaitu nilai $\mathrm{r}$ hitung lebih besar dari $r$ tabel 0.2319 .

\section{Uji Reliabilitas}

Uji reliabilitas bertujuan untuk melihat apakah kuesioner memiliki konsistensi jika pengukuran dilakukan dengan kuesioner tersebut dilakukan secara berulang. Uji reliabilitas dapat dilakukan secara bersama-sama terhadap seluruh item kuesioner dalam suatu variabel penelitian. Sebuah penelitian dikatakan berkualitas jika sudah terbukti validitas dan reliabilitasnya. Menurut Sujerweni (2014), kuesioner dikatakan reliable jika nilai cronbach alpha $>0,6$. Pada penelitian ini setiap variabel terbukti reliabel dengan penjabaran pada tabel dibawah ini:

Tabel 1. Hasil Uji Reliabilitas

\begin{tabular}{lcccc}
\hline \multicolumn{1}{c}{ Variabel } & $\begin{array}{c}\text { Cronbach } \\
\text { Alpha }\end{array}$ & $\begin{array}{c}\text { Nilai kritis } \\
(\boldsymbol{\alpha})=\mathbf{5 \%}\end{array}$ & N. Item & Keterangan \\
\hline Karakteristik Individu & 0.923 & 0.600 & 12 & Reliabel \\
Faktor Lingkungan & 0.859 & 0.600 & 12 & Reliabel \\
Keputusan Pembelian & 0.926 & 0.600 & 16 & Reliabel \\
\hline
\end{tabular}

Berdasarkan reliabilitas cronbach alpha tersebut tampak bahwa seluruh pernyataan yang ada membentuk ukuran yang reliabel karakteristik individu, faktor lingkungan dan keputusan pembelian membentuk ukuran yang reliabel dari masing-masing variabel

Tabel 2: Pengaruh Karakteristik Individu Terhadap Keputusan Pembelian

\begin{tabular}{|c|c|c|c|c|c|}
\hline \multirow[b]{2}{*}{ Variabel } & \multicolumn{5}{|c|}{ Parameter } \\
\hline & $\mathbf{R}$ & R Square & Konstanta & $\begin{array}{c}\text { Koefisien } \\
\text { Regresi }\end{array}$ & Sig. \\
\hline $\begin{array}{l}\text { Karakteristik } \\
\text { Individu }\end{array}$ & 0.728 & 0.530 & 12.617 & 0.929 & 0.000 \\
\hline \multicolumn{6}{|c|}{ Pengujian Signifikansi } \\
\hline \multicolumn{6}{|c|}{$\mathrm{t}$ hitung $>\mathrm{t}$ tabel $=8.890>1.994$} \\
\hline
\end{tabular}

Berdasarkan Tabel 2, nilai koefisien determinasi $\left(\mathrm{R}^{2}\right)$ sebesar 0.530 , artinya karakteristik individu memberikan kontribusi sebesar 53,0\% kepada keputusan pembelian produk asuransi jiwa unit link di Jakarta, sedangkan sisanya sebesar $47,0 \%$ 
disumbangkan faktor lain yang tidak diteliti, seperti faktor lingkungan.

Persamaan Regresi $\mathrm{Y}=12,617+0,929$ $\left(\mathrm{X}_{1}\right)$

Koefisien karakteristik individu sebesar 0.929, bertanda positif, artinya jika ada peningkatan karakteristik individu, maka keputusan pembelian produk asuransi jiwa unit link di Jakarta akan lebih baik atau sebaliknya.

Tabel 3: Pengaruh Faktor Lingkungan Terhadap Keputusan Pembelian

\begin{tabular}{|c|c|c|c|c|c|}
\hline \multirow[b]{2}{*}{ Variabel } & \multicolumn{5}{|c|}{ Parameter } \\
\hline & $\mathbf{R}$ & R Square & Konstanta & $\begin{array}{c}\text { Koefisien } \\
\text { Regresi }\end{array}$ & Sig. \\
\hline $\begin{array}{l}\text { Faktor } \\
\text { Lingkungan }\end{array}$ & 0.582 & 0.339 & 19.091 & 0.788 & 0.000 \\
\hline \multicolumn{6}{|c|}{ Pengujian Signifikansi } \\
\hline \multicolumn{6}{|c|}{ t hitung $>\mathrm{t}$ tabel $=5.986>1.994$} \\
\hline
\end{tabular}

Berdasarkan Tabel 3, nilai koefisien determinasi $\left(\mathrm{R}^{2}\right)$ sebesar 0.339, artinya faktor lingkungan memberikan kontribusi sebesar 33,9\% kepada keputusan pembelian produk asuransi jiwa unit link di Jakarta, sedangkan sisanya sebesar $66,1 \%$ disumbangkan faktor lain yang tidak diteliti, seperti karakteristik individu.
Persamaan Regresi $\mathrm{Y}=19,091+0,788$ $\left(\mathrm{X}_{2}\right)$

Koefisien faktor lingkungan sebesar 0.788 , bertanda positif, artinya jika ada peningkatan faktor lingkungan, maka keputusan pembelian produk asuransi jiwa unit link di Jakarta akan lebih baik atau sebaliknya.

Tabel 4. Pengaruh Karakteristik Individu dan Faktor Lingkungan Terhadap Keputusan Pembelian

\begin{tabular}{|c|c|c|c|c|c|}
\hline \multirow[b]{2}{*}{ Variabel } & \multicolumn{5}{|c|}{ Parameter } \\
\hline & Mult. R & $\begin{array}{c}\mathbf{R} \\
\text { Square }\end{array}$ & Konstanta & $\begin{array}{c}\text { Koefisien } \\
\text { Regresi }\end{array}$ & Sig. \\
\hline Karakteristik & & & & 0,651 & 0,000 \\
\hline $\begin{array}{l}\text { Individu } \\
\text { Faktor } \\
\text { Lingkungan }\end{array}$ & 0,735 & 0,540 & 8,386 & 0,406 & 0,000 \\
\hline \multicolumn{6}{|c|}{ Pengujian Signifikan } \\
\hline \multicolumn{6}{|c|}{ F hitung $>\mathrm{F}$ tabel $=40,537>3,128$} \\
\hline
\end{tabular}

Berdasarkan Tabel 4, pada penelitian ini, merujuk tabel $\mathrm{F}$ hitung yang dihasilkan adalah 40,537 dimana lebih besar daripada $\mathrm{F}$ tabel 3,128 dan nilai signifikansi 0,00 dimana lebih kecil daripada 0,05 , sehingga dapat disimpulkan bahwa karakteristik individu dan faktor lingkungan secara bersamasama mempunyai pengaruh terhadap keputusan pembelian produk asuransi jiwa unit link di Jakarta. Nilai koefisien determinasi $\left(\mathrm{R}^{2}\right)$ sebesar 0.540 , artinya karakteristik individu dan faktor lingkungan secara bersama-sama 
memberikan kontribusi sebesar 54,0\% kepada keputusan pembelian produk asuransi jiwa unit link di Jakarta, sedangkan sisanya sebesar $46,0 \%$ disumbangkan faktor lain yang tidak dibahas dalam penelitian ini.

Persamaan Regresi $\mathrm{Y}=8,386+0,651$ $\left(\mathrm{X}_{1}\right)+0,406\left(\mathrm{X}_{2}\right)$

Koefisien regresi karakteristik individu bernilai positif artinya jika ada peningkatan karakteristik individu, maka keputusan pembelian produk asuransi jiwa unit link di Jakarta juga akan mengalami perbaikan.

Koefisien regresi faktor lingkungan bernilai positif memiliki arti jika faktor lingkungan menguat, maka keputusan pembelian produk asuransi jiwa unit link di Jakarta mengalami perbaikan.

\section{Pembahasan}

\section{Pengaruh Karakteristik Individu Terhadap Keputusan Pembelian}

Hasil penelitian ini menunjukkan bahwa karakteristik individu mendorong peningkatan keputusan pembelian. Hal ini dikarenakan bahwa dimana faktor internal konsumen seperti motivasi, kepribadian, persepsi, pengetahuan dan sikap dari konsumen berpengaruh terhadap pengambilan keputusan pembelian yang akan dilakukannya terhadap suatu produk asuransi jiwa dan investasi (unit link).

\section{Pengaruh Faktor Lingkungan Terhadap Keputusan Pembelian}

Hasil penelitian ini menunjukkan bahwa faktor lingkungan mendorong peningkatan keputusan pembelian. Hal ini dikarenakan bahwa dimana faktor lingkungan seperti budaya, keluarga, reference grup, juga berpengaruh terhadap pengambilan keputusan pembelian produk asuransi jiwa dan investasi (unit link).

\section{Pengaruh Karakteristik Individu dan Faktor Lingkungan Terhadap Keputusan Pembelian}

Hasil penelitian ini menunjukkan bahwa karakteristik individu dan faktor lingkungan mendorong peningkatan keputusan pembelian produk asuransi jiwa unit link di Jakarta.

\section{KESIMPULAN DAN SARAN}

\section{Kesimpulan}

Berdasarkan hasil dari pengolahan data penelitian dapat disimpulkan bahwa: 1). Karakteristik individu berpengaruh signifikan terhadap keputusan pembelian, 2). Faktor lingkungan dalam penelitian ini ditemukan juga berpengaruh signifikan terhadap keputusan pembelian. 3). Karakteristik individu dan faktor lingkungan secara bersama-sama berpengaruh terhadap keputusan pembelian produk asuransi jiwa unit link di Jakarta.

\section{Saran}

Berdasarkan hasil penelitian ini, faktor karakteristik individu dan faktor lingkungan berpengaruh signifikan terhadap keputusan pembelian yang akan diambil oleh konsumen, maka dari itu dalam penjualan asuransi jiwa (unit link) penting untuk memberikan edukasi yang tepat mengenai produk yang dapat lebih mengakomodir kebutuhan personal dan kelompok. Saran untuk penelitian selanjutnya adalah dengan lebih mengeksplorasi media apa yang paling efektif untuk menjadi sarana edukasi dengan konsumen.

\section{DAFTAR PUSTAKA}

https://sikapiuangmu.ojk.go.id/FrontEnd/ CMS/Article/91

https://keuangan.kontan.co.id/news/unitli nk-berkontribusi-besar-terhadaptotal-premi-asuransi-jiwa-kuartal$\underline{\text { iii-2019 }}$ 
https://republika.co.id/berita/pvjowl383/o jk-masyarakat-indonesia-belum-sadarasuransi

https://republika.co.id/berita/pxnp13383/ bisnis-asuransi-unitlink-bisa-tumbuh-50persen

https://investor.id/finance/unit-link-berikontribusi-584-premi-asuransi-jiwa https://keuangan.kontan.co.id/news/minat -masyarakat-bergeser-kontribusipremi-produk-asuransi-jiwatradisional-turun

https://sikapiuangmu.ojk.go.id/FrontEnd/ CMS/Article/10

https://diskartes.com/2016/10/unitlinktidak-menguntungkan/

B. Uno, Hamzah. 2007. Teori Motivasi dan Pengukurannya. Jakarta: Bumi Aksana.

Dharmmesta dan Irawan, 2000. Manajemen Pemasaran Modern, Edisi II, Liberty, Yogyakarta.

Elliot, S.N, et al, 2000. Educational Psychology: Effective Teaching, Effective. Learning. Singapore: Mc Graw-Hill

Engel, Blackwell, dan Miniard. 1994. Perilaku Konsumen. Jakarta: Binarupa
Gibson, James, L., 2000, Organisasi, Perilaku, Struktur dan Proses, Edisi ke-5 Herman Sofyandi, Iwa Garniwa. 2007. Perilaku Organisasional. Yogyakarta: Graha Ilmu

Philip Kotler and Kevin Lane Keller.2006. Marketing management. London : Prentice Hall

Robbins, S., dan Timothy A. J., 2008, Perilaku Organisasi, Organizational Behaviour, Buku Terjemahan, Jakarta.

Robbins , Stephen P. \& Timothy A.Judge. 2008. Perilaku Organisasi. Edisi 12. Jakarta: Salemba Empat

Siagian, Sondang P, 2004. Manajemen Sumber Daya Manusia. Jakarta: Bumi.

Sugiyono. 2009. Metode Penelitian Kuantitatif Kualitatif dan $R \quad \& \quad D$. Bandung: Alfabeta.

Herman Sofyandi, Iwa Garniwa. 2007. Perilaku Organisasional. Yogyakarta: Graha Ilmu.

U Nimran, 1997. Perilaku Organisasi. CV Citra Media, Surabaya. 